\title{
Catalyst-Free Synthesis of Thiosemicarbazone and Rhodanine derivatives and Their Schottky Diode Applications
}

\author{
Sinan BAYINDIR ${ }^{1}$, Mehmet Akif ŞAHINKAYA ${ }^{2}$, İkram ORAK ${ }^{3 *}$
}

\begin{abstract}
In the present study, organic materials Bis(TSC)-Ph and novel $\mathrm{Bis}(\mathrm{Rh})-\mathrm{Ph}$ were synthesized and used such as interfacial layer for diode applications. Al/ Bis(TSC)-Ph/p type Si and $\mathrm{Al} / \mathrm{Bis}(\mathrm{Rh})-\mathrm{Ph} / \mathrm{p}$ type $\mathrm{Si}$ Schottky diodes were fabricated with spin coating and thermal evaporation methods. The electrical parameters were investigated by using capacitance-voltage $(\mathrm{C}-\mathrm{V})$ and conductance-voltage $(\mathrm{G}-\mathrm{V})$ measurements at various frequencies from $30 \mathrm{kHz}$ to $5 \mathrm{Mhz}$ at room temperature. The effect of frequency on device performance was examined and compared with each other. The some basically parameters such as acceptor concentration $\left(\mathrm{N}_{\mathrm{a}}\right)$, interface states $\left(\mathrm{N}_{\mathrm{ss}}\right)$, Fermi level $\left(\mathrm{E}_{\mathrm{f}}\right)$ and barrier height $\left(\Phi_{B}\right)$ were also calculated from $\mathrm{C}^{-2}-\mathrm{V}$ measurements. According to these results, as expected, it was determined that $\mathrm{Bis}(\mathrm{Rh})-\mathrm{Ph}$ organic layer, which is containing the rhodanine group, is more suitable than Bis(TSC)-Ph for $\mathrm{C}-\mathrm{V}$ and $\mathrm{G}-\mathrm{V}$ performances.
\end{abstract}

Keywords: Schottky diode, MPS structures, Organic molecules

\section{Tiyosemikarbazon ve Rodanin Türevlerinin Katalizörsüz Sentezi ve Onların Schottky Diyot Uygulamaları}

ÖZET: $\mathrm{Bu}$ çalışmada, $\mathrm{Bis}(\mathrm{TSC})-\mathrm{Ph}$ ve yeni $\mathrm{Bis}(\mathrm{Rh})-\mathrm{Ph}$ organik malzemeleri sentezlendi ve diyot uygulamaları için arayüzey elemanı olarak kullanıld. Al/Bis(TSC)-Ph/p-Si ve Al/ Bis(Rh)-Ph/p-Si Schottky diyotları termal buharlaştırma ve döndürme metodları ile fabrikasyonları yapıldı. Oda sicaklığında $30 \mathrm{kHz}$ ile $5 \mathrm{MHz}$ aralığında çeşitli frekanslarda kapasitans-voltaj (C-V) ve kondüktansvoltaj (G-V) ölçümleri kullanılarak elektriksel parametreler incelendi. Aygıt performansında frekansın etkisi incelendi ve her bir diyot için karşılaştırıldı. Akseptör konsantrasyonu $\left(\mathrm{N}_{\mathrm{a}}\right)$, arayüzey durumları $\left(\mathrm{N}_{\mathrm{ss}}\right)$, Fermi seviyesi $\left(\mathrm{E}_{\mathrm{f}}\right)$ ve bariyer yüksekliği $\left(\Phi_{\mathrm{b}}\right)$ gibi bazı temel parametreler $\mathrm{C}^{-2}-\mathrm{V}$ ölçümlerinden hesapland1. $\mathrm{Bu}$ sonuçlara göre, beklendiği gibi, rodanin grubunu içeren $\mathrm{Bis}(\mathrm{Rh})-\mathrm{Ph}$ organik katmanının C-V ve G-V performansları için Bis (TSC)-Ph'den daha uygun olduğu tespit edilmiştir.

Anahtar Kelimeler: Schottky diyot, MPS yapılar, Organik moleküller

\footnotetext{
${ }^{1}$ Sinan Bayındır (Orcid ID: 0000-0002-7845-4497), Department of Chemistry, Faculty of Sciences and Art, Bingol University, Bingol, Turkey

${ }^{2}$ Mehmet Akif Şahinkaya ${ }^{2}$ (Orcid ID: 0000-0001-6461-8959), Department of Physics, Faculty of Sciences and Art, Bingol University, Bingol, Turkey

${ }^{3}$ İkram Orak (Orcid ID: 0000-0003-2318-9718), Vocational School of Health Services, Bingol University, Bingol, Turkey *Sorumlu Yazar / Corresponding Author: İkram Orak, e-mail: ikramorak@gmail.com
} 


\section{INTRODUCTION}

Recently, the organic interfacial materials are commonly used some electronic and optoelectronic device applications between metal and semiconductor (Majumdar et al., 2009; Aksoy and Caglar, 2012). These structures are called metal-polymer-semiconductor (MPS). MPS structures play a major role in the improvement of electronic and optoelectronic integrated circuit performance. The organic interfacial materials are used in diode, thin film transistor and solar cell applications(Kaçus et al.; Kaya et al., 2016; Oruc et al.,2015; Orak et al.,2015). MPS structures have been examined by many scientists and their electrical properties have been revealed by different fabrication processes. One of the most important fabrication processes is the spin coating technique. This technique has many advantages such as cheap, easy coating and surface homogeneity(Karabulut et al.,2018; Güclü et al.,2019). Especially, the efficiency and electrical performance of MPS structure are depend on some parameters such as conduction mechanism, frequency, temperature, inhomogeneity surface preparation, growth, thickness, series resistance (Rs) and barrier height(Cifci et al., 2018; Bilkan et al.,2015). Organic-inorganic Schottky junction have been fabricated with polyethylene oxide (PEO). Some electrical parameter of this device such as interface states and series resistance calculated capacitance and conductance experimental measurements (Padma et al.,2017). Dielectric constant and dielectric loss calculated with various frequencies. The material used in the interface layer has an important role in influencing the electrical parameters. The existence of an interfacial layer, the performances of device also affects in a positive or negatively. Otherwise, doping metal particles to the organic interface layer, the performance of the devices has been increased. The electrical characteristics of devices depend on used interface layers(Tanrıkulu et al.,2018).
In this study, the organic interfacial materials were used to improve the efficiency and electrical performance of the conduction mechanism. the organic materials such as $\mathrm{Bis}(\mathrm{TSC})-\mathrm{Ph}$ and $\mathrm{Bis}(\mathrm{Rh})-\mathrm{Ph}$ were synthesized. The Al/Bis(TSC)-Ph/p-Si and Al/Bis(Rh)-Ph/p$\mathrm{Si}$ were fabricated for Schottky diode applications. C-G-V characteristics were investigated and some main electrical parameters were calculated as function of frequency and voltage. The performances of $\mathrm{C}$ and $\mathrm{G}$ were compared with each other.

\section{MATERIAL AND APPARATUS}

All chemicals and solvents were commercially available from Merck or SigmaAldrich. ${ }^{1} \mathrm{H}$ NMR and ${ }^{13} \mathrm{C}$ NMR spectra were recorded on a 400 (100)-MHz Bruker spectrometer.

\section{Synthesis of bis-thiosemicarbazone (TSC) and bis-rhodanine (Rh)-appended phenyl derivatives}

The synthesis of $B i s(T S C)-P h$ : To a solution of 1,1'-(1,4-phenylene)bis(ethan-1-one) $(1,100.0 \mathrm{mg}, 0.62 \mathrm{mmol})$ in ethanol $(10 \mathrm{~mL})$ was added slowly to the solution of hydrazinecarbothioamide (2, TSC, $112.0 \mathrm{mg}$, $1.24 \mathrm{mmol}$ ) using dropwise. The reaction mixture was stirred for overnight at room temperature without catalyst, and was monitored by TLC. After the completion of the reaction, the red product formed was recrystallized from ethanol, filtered, and dried in vacuo. After recrystallization, Bis(TSC)-Ph (201.0 mg, 81\%) was obtained as isomeric mixture. ${ }^{1} \mathrm{H}-\mathrm{NMR}$ (400 MHz, DMSO-d6): $\delta 10.23$ (s, NH, 2H), 8.52 (bs, $\left.\mathrm{NH}_{2}, 2 \mathrm{H}\right), 8.19$ (bs, $\left.\mathrm{NH}_{2}, 2 \mathrm{H}\right), 7.88-7.83$ (m, $=\mathrm{CH}, 4 \mathrm{H}), 2.24\left(\mathrm{~s}, \mathrm{CH}_{3}, 6 \mathrm{H}\right)$. The obtained spectral data are consistent with the literature(Liu et al., 2008)

The synthesis of $B i s(R h)-P h$ : To a solution of 1,1'-(1,4-phenylene)bis(ethan-1-one) (1, 100.0 $\mathrm{mg}, 0.62 \mathrm{mmol})$ in ethanol $(10 \mathrm{~mL})$ was added slowly to the solution of 3-amino-2- 
thioxothiazolidin-4-one (3, Rh, $182.0 \mathrm{mg}, 1.24$ mmol) using dropwise. The reaction mixture was stirred for overnight at room temperature without catalyst, and was monitored by TLC. After the completion of the reaction, the red product formed was recrystallized from ethanol, filtered, and dried in vacuo. After recrystallization, $\mathrm{Bis}(\mathrm{Rh})-\mathrm{Ph}$ (241.0 $\mathrm{mg}$, 92\%) was obtained as yellow solid (m.p. $\left.>300^{\circ} \mathrm{C}\right) .{ }^{1} \mathrm{H}-\mathrm{NMR}(400 \mathrm{MHz}$, DMSO-d6): $\delta$ 8.13-8.10 (m, =CH, 4H), 4.44 (bs, $\left.\mathrm{CH}_{2}, 4 \mathrm{H}\right), 2.29\left(\mathrm{~s}, \mathrm{CH}_{3}, 6 \mathrm{H}\right) ;{ }^{13} \mathrm{C}-\mathrm{NMR}(100$ MHz, DMSO-d6): $\delta$ 195.7, 177.7, 168.9, 138.2, 128.0, 35.2, 17.2.

\section{Chemistry}

To endow the phenyl-based organic semiconductor with new functionalities and broaden their useful applications, we designed the molecular structures of a group of bis- thiosemicarbazone (TSC) or bis-rhodanine (Rh)appended phenyl derivatives (Bis(TSC)-Ph and $B i s(R h)-P h)$ and elaborated one-step reaction routes for their syntheses (Figure 1). Our research aim to synthesize of bisthiosemicarbazone (TSC) derivative or new derivative of bis-rhodanine (Rh)-appended phenyl derivative by a green approach and to investigate the photoresponsivity properties of these ligands. In this context, the reaction of 1,1'(1,4-phenylene)bis(ethan-1-one) (1) with two equivalent of TSC (2) and two equiv. of Rh (3) in ethanol at room temperature gave compounds $B i s(T S C)-P h$ and $B i s(R h)-P h)$ in $94 \%$, and $92 \%$ yields, respectively (Figure 1A and 1B). Detailed procedures and characterization can be found in the experimental section and Figure 2.

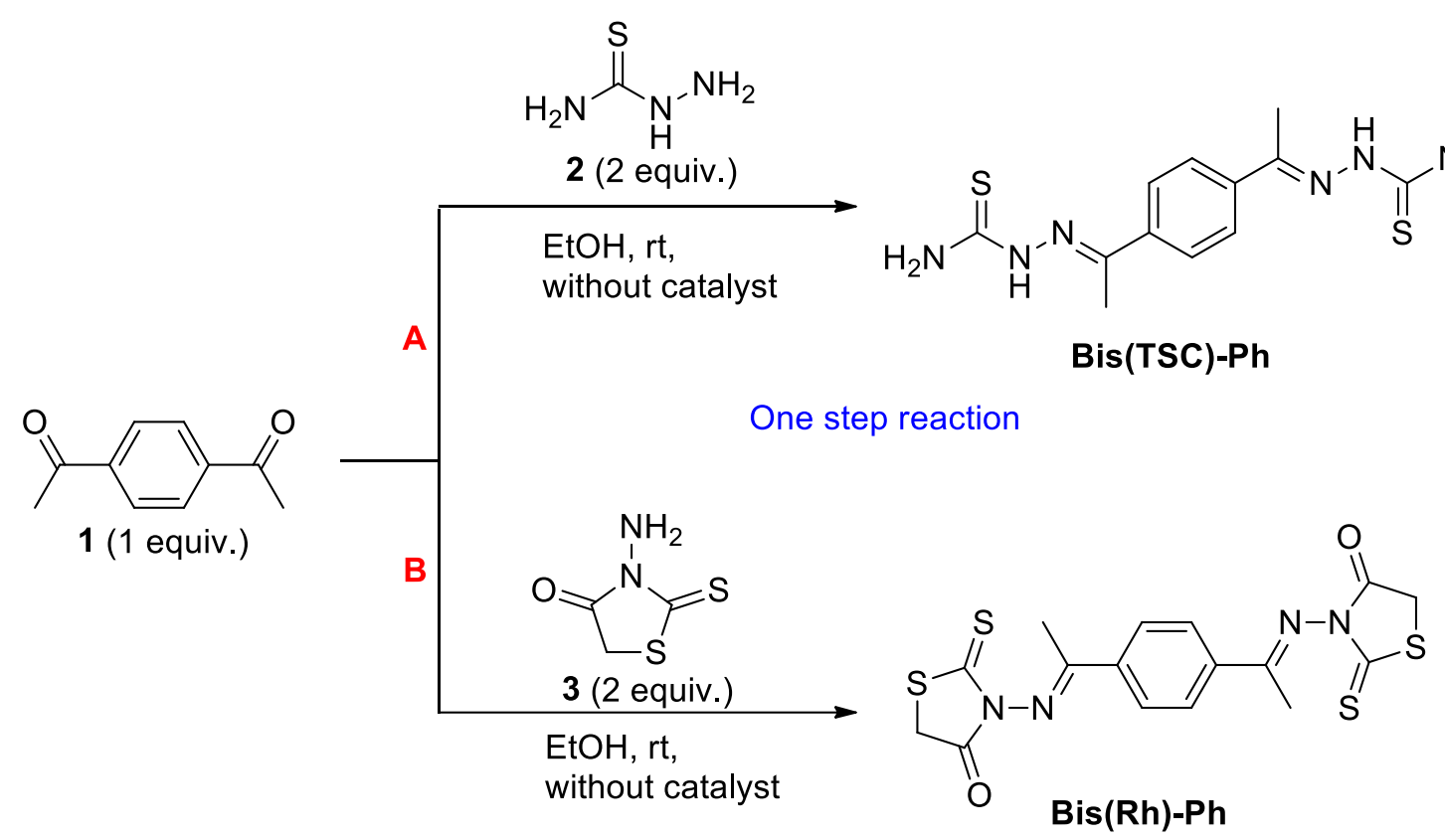

Figure 1. Synthesis of $B i s(T S C)-P h$ and $B i s(R h)-P h$

The synthesis of the novel bis-rhodanine (Rh)-appended phenyl derivative $(B i s(R h)-P h)$ was also carried out with a green and effective approach in this study. The photo physical properties of $B i s(R h)-P h$ were compared with another compound Bis(TSC)-Ph. The ${ }^{1} \mathrm{H}$ NMR and APT ${ }^{13} \mathrm{C}$ NMR spectra of bis-rhodanine (Rh)-appended phenyl derivative $(B i s(R h)-P h)$ are shown in Figure 2. When the ${ }^{1} \mathrm{H}$ NMR spectrum of $B i s(R h)-P h$ is examined, it is seen that the four aromatic $=\mathrm{CH}$ proton peaks are resonance at $8.13-8.10(\mathrm{~m},=\mathrm{CH}, 4 \mathrm{H}) \mathrm{ppm}$. 
(A)
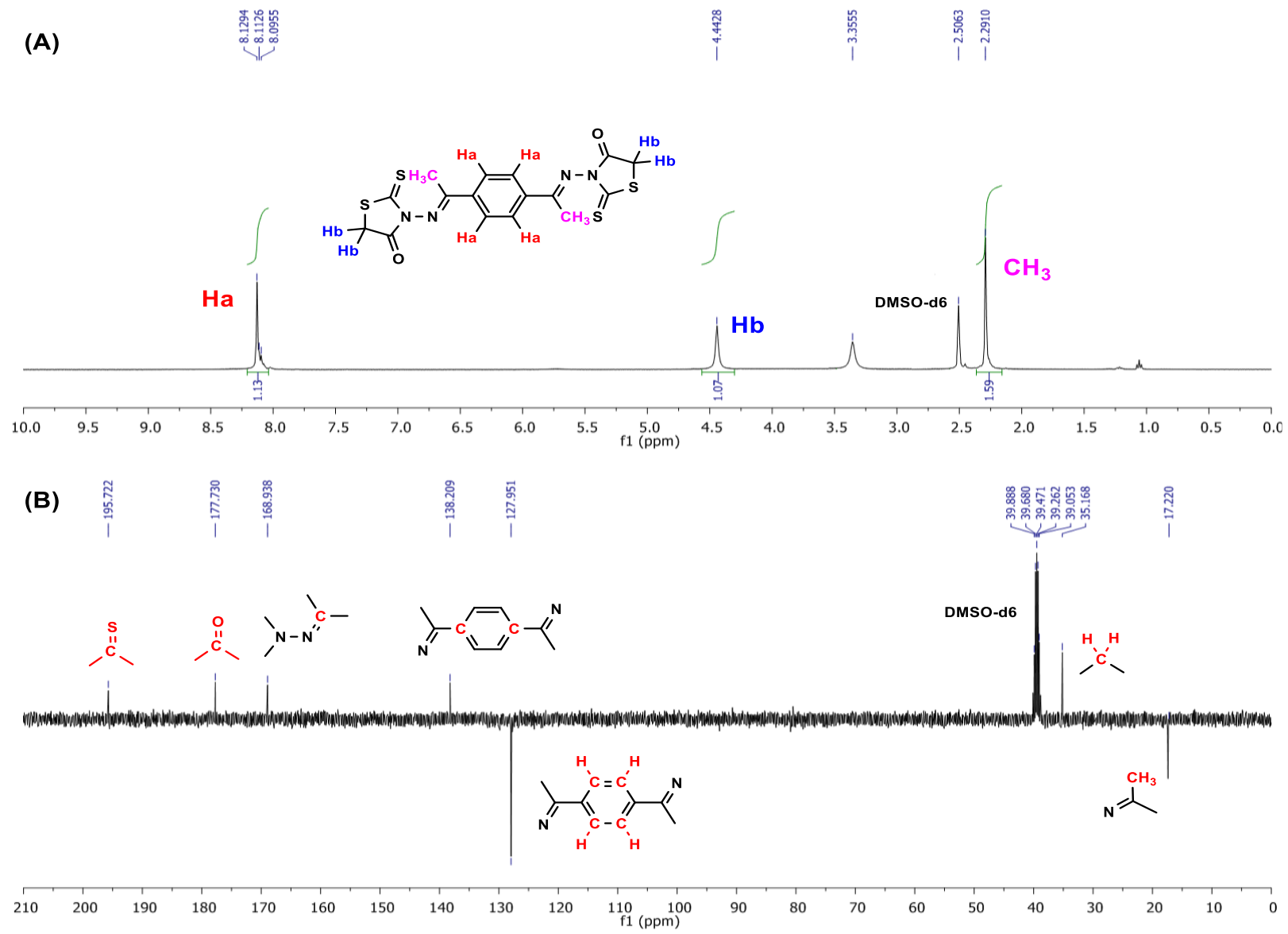

Figure 2. ${ }^{1} \mathrm{H}$ NMR (A) and APT ${ }^{13} \mathrm{C}$ NMR (B) spectrums of Bis(Rh)-TPE.

At the same time, it is seen that protons of $\mathrm{CH}_{2}$ and $\mathrm{CH}_{3}$ groups in the structure of the target molecule gave resonances signals at 4.44 (bs, $\left.\mathrm{CH}_{2}, 4 \mathrm{H}\right) \mathrm{ppm}$ and $2.29\left(\mathrm{~s}, \mathrm{CH}_{3}, 6 \mathrm{H}\right) \mathrm{ppm}$, respectively (Figure 2A). On the other hand, when the ${ }^{13} \mathrm{C}$ NMR spectrum of Bis $(\mathrm{Rh})-\mathrm{Ph}$ is examined, it is seen that seven carbon resonance signals are resonance at 195.7, 177.7, 168.9, 138.2, 128.0, 35.2, and $17.2 \mathrm{ppm}$ (Figure 2B). The presence of aza-ylide group carbon $(\mathrm{N}$ $\mathrm{N}=\mathrm{CH}-$ ) peak which is resonance at $168.9 \mathrm{ppm}$ is the most important indicator that the reaction has taken place and that the target product is obtained (Figure 2B).

The fabrication of $\mathrm{Al} / \mathrm{Bis}(\mathrm{TCS})-\mathrm{Rh}$ and $\operatorname{Bis}(\boldsymbol{R h})$-Ph/p-type $\mathrm{Si} / \mathrm{Al}$ heterojunctions

The experimental procedure and the device of schematic diagrams were also given in Figure 3. The double polished side $p$-type Si (111) wafer with $525 \mu \mathrm{m}$ thickness and 3-5 $\Omega$-cm resistivity was used as substrate wafer for MPS structures. Before ohmic contact, the wafer was cut into small part such as $2.0 \times 2.0 \mathrm{~mm}^{2}$ area. Firstly, the small pieces were first washed in an ultrasonic bath with deionize (DI) water. Secondly, the small semiconductor pieces were basically cleaned using the RCA1 and RCA2 cleaning procedure. Then the native oxide layer was removed by HF (1:20) for $30 \mathrm{~s}$, and then the rinsed by DI water and dried by high-purity nitrogen. For ohmic contact, aluminum metal was deposited on the $\mathrm{p}-\mathrm{Si}$ by using thermal evaporation technique at $10^{-6}$ torr. Homogeneous solutions of $B i s(T C S)-R h$ and $B i s(R h)-P h$ $(0.005 \mathrm{~g} / \mathrm{ml})$ were prepared in chloroform. The $\operatorname{Bis}(T C S)-R h$ and $B i s(R h)-P h$ solutions are directly doped on the p-Si substrate with spin coating technique which was rotated $2000 \mathrm{rpm}$ 
for $30 \mathrm{~s}$. Finally, the same high purity $\mathrm{Al}$ rectifying contacts, which formed from by using thermal evaporation technique circular dots of 1 $\mathrm{mm}$ diameter or $\left(7.85 \times 10^{-3} \mathrm{~cm}^{2}\right)$ area, at a pressure of $\sim 10^{-6}$ torr. The Al film thickness is about $150 \mathrm{~nm}$ and diameter of about on front of sample surface. The $C-V$ characterizations were measured a HP model 4192A LF impedance analyzer various frequency at room temperature.

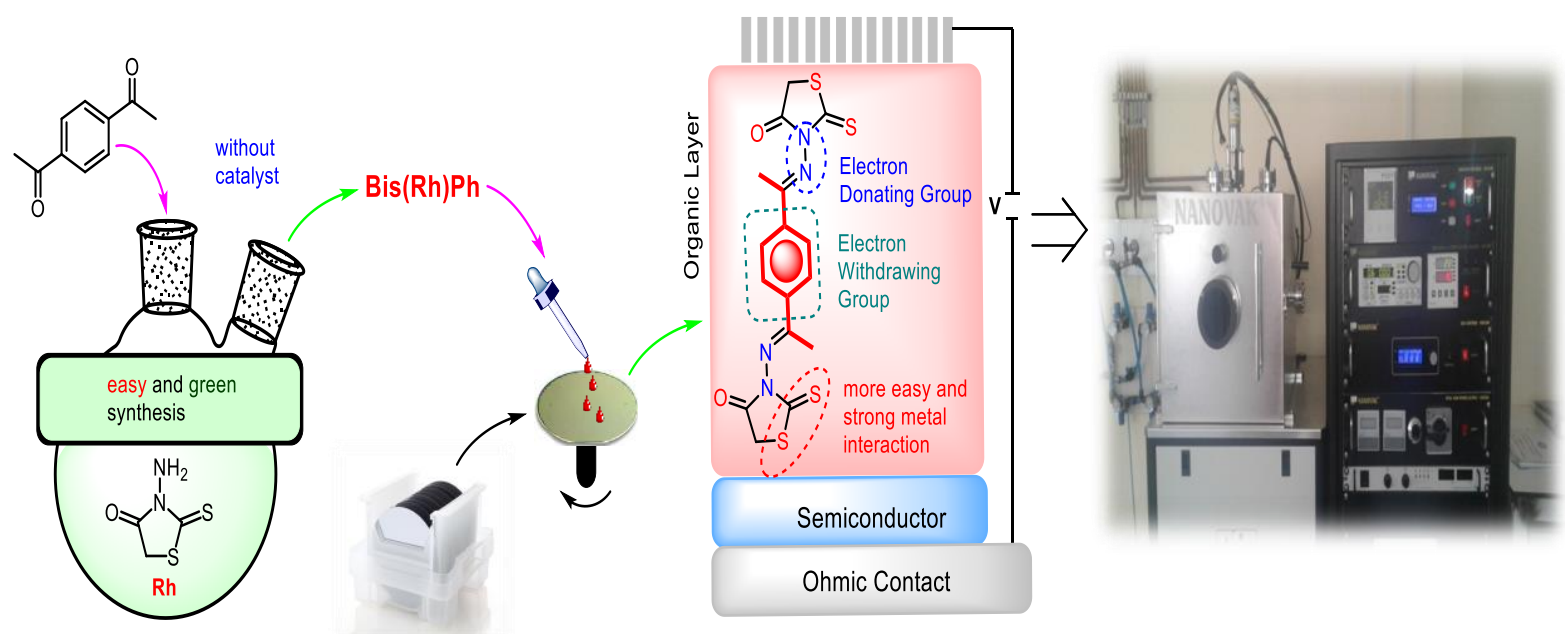

Figure 3. Schematic diagrams of $\mathrm{Al} / \mathrm{Bis}(R h)-P h$ structures

\section{RESULT AND DISCUSSION}

In order to understand and relate the Schottky diode operation to device parameters, $\mathrm{C}-\mathrm{V}$ and $\mathrm{G}-\mathrm{V}$ characteristics of $\mathrm{Al} / \mathrm{Bis}$ (TSC)$\mathrm{Rh} / \mathrm{p}-\mathrm{Si}$ and $\mathrm{Al} / \mathrm{Bis}(\mathrm{Rh})-\mathrm{Ph} / \mathrm{p}-\mathrm{Si}$ Schottky diode that they called D1 and D2 device were measured in the various frequency range 30 $\mathrm{kHz}-5 \mathrm{MHz}$ at room temperature, as can be seen in Figure 4 and 5. It is clearly in Figure 4a, the capacitance values increased with increasing applied voltage and decreased with increasing frequency. The capacitance value has maximum peak the high-frequency values at about $1.3 \mathrm{~V}$ such as $2 \mathrm{MHz}$ and $5 \mathrm{MHz}$. After $3 \mathrm{~V}$, the capacitance values reach a constant value all frequency. Besides, in Figure $4 b$, the conductance values increased with increasing frequency and applied voltage. The reason for the effect in capacitance and conductance is attributed to the series resistance and interfacial states (Bilkan et al., 2015; Karabulut, 2019).

On the other hands, some crucial parameters such as donor consantration $\left(\mathrm{N}_{\mathrm{a}}\right)$, interface states $\left(\mathrm{N}_{\mathrm{ss}}\right)$, Series resistance $\left(\mathrm{R}_{\mathrm{s}}\right)$, Barrier height $(\Phi)$ and Fermi level $\left(\mathrm{E}_{f}\right)$ maximum electric field $\left(E_{m}\right)$ were calculated by using $1 / \mathrm{C}^{2}-\mathrm{V}$ ploth in Figure $4 \mathrm{c}$.

These parameters were listed in Table 1 for various frequencies. The values of $\mathrm{N}_{\mathrm{ss}}$ changing are calculated with following formula:

$$
N_{S S}=\frac{2}{q A} \frac{\left(G_{m} / \omega\right)_{\max }}{\left(\left(G_{m} / \omega\right)_{\max } / C_{0 x}\right)^{2}+\left(1-C_{m} / C_{0 x}\right)^{2}}
$$

where $A$ is contact area and $\omega$ is angular frequency. $C_{m}$ and $G_{m}$ represent measured capacitance and conductance at $3 \mathrm{~V}$ and, $C_{0 x}$ is oxide capacitance for accumulation region: 


$$
C_{0 x}=C_{m a}\left[1+\frac{G_{m a}^{2}}{\left(\omega C_{m a}\right)^{2}}\right]
$$

The values of barrier height are calculated with following equation:

$$
\Phi_{b}(C-V)=\left(V_{d}+E_{F}\right)-\Delta \Phi
$$

Series resistance can be determined Nicollian and Brews method and it calculated via following formula:

$$
R_{s}=\frac{G_{m a}}{G_{m a}^{2}+\left(\omega C_{m a}\right)^{2}}
$$
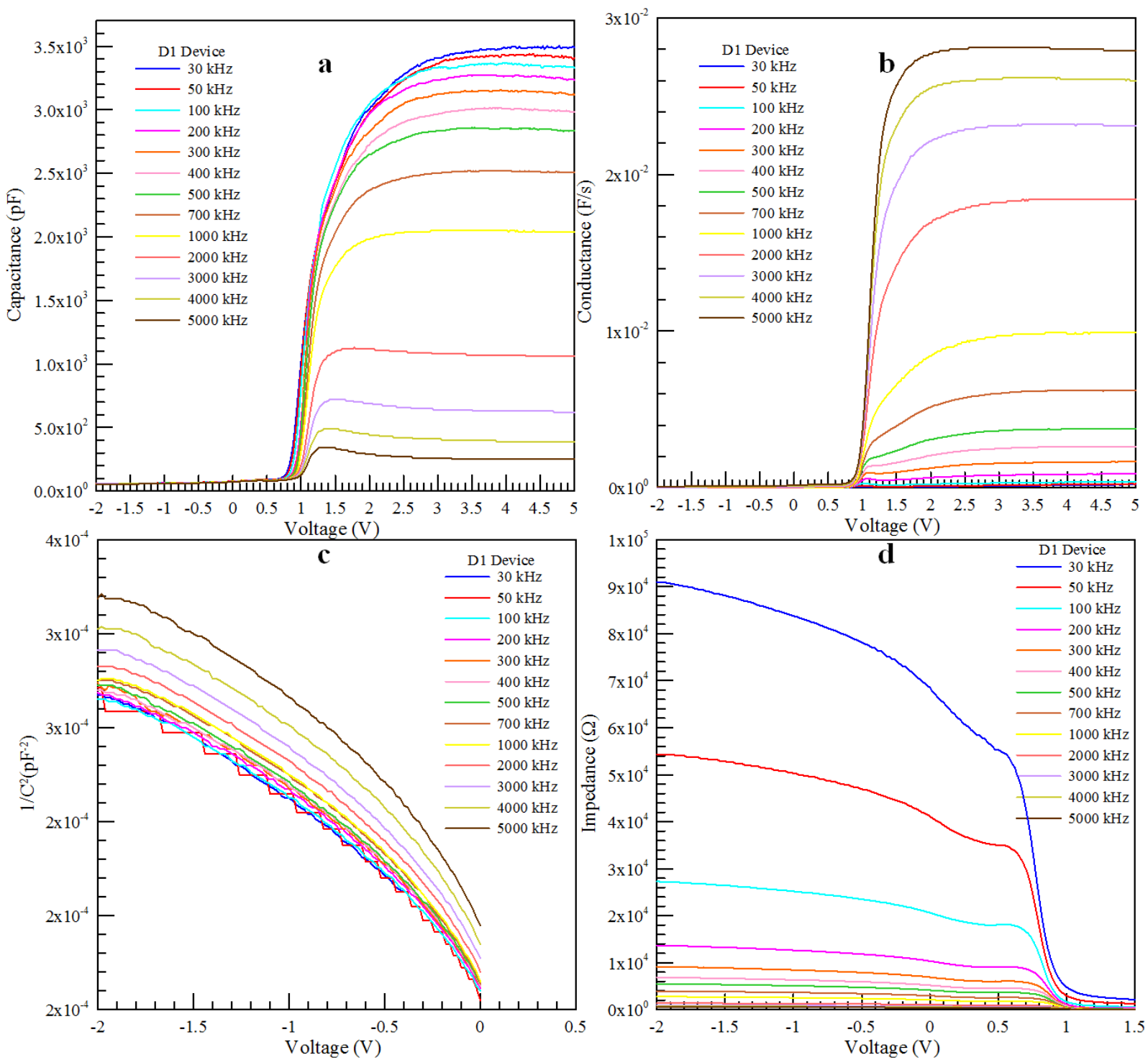

Figure 4. The electrical characteristics of Bis(TSC)-Rh/p-Si Schottky diode at various frequencies a) $\mathrm{C}-\mathrm{V}$ measurement, b) G-V measurements, c) $1 / \mathrm{C}^{2}-\mathrm{V}$, d) $\mathrm{Z}-\mathrm{V}$ plot. 
Table 1. The some electrical parameters of Bis(TSC)-Rh/p-Si Schottky diode MPS contact obtained from $\mathrm{C}-\mathrm{G}-\mathrm{V}$ and $\mathrm{C}^{-2}-\mathrm{V}$ at various frequencies

\begin{tabular}{ccccccccc}
\hline $\boldsymbol{f}(\mathbf{k H z})$ & $\begin{array}{c}\boldsymbol{N}_{\boldsymbol{a}} \\
\left(\mathbf{c m}^{-\mathbf{3}}\right) \\
\left(\mathbf{1 0}^{\mathbf{1 5}}\right)\end{array}$ & $\boldsymbol{V}_{\boldsymbol{d}}(\mathbf{V})$ & $\begin{array}{c}\boldsymbol{E}_{\boldsymbol{F}} \\
(\mathbf{e V})\end{array}$ & $\begin{array}{c}\Delta \boldsymbol{\Phi}_{\boldsymbol{b}} \\
(\mathbf{e V})\end{array}$ & $\begin{array}{c}\boldsymbol{\Phi}_{\boldsymbol{b}} \\
(\mathbf{e V})\end{array}$ & $\begin{array}{c}\boldsymbol{E}_{\boldsymbol{m}}(\mathbf{V} / \mathbf{m}) \\
(\mathbf{1 0})\end{array}$ & $\begin{array}{c}\boldsymbol{N}_{\boldsymbol{s s}}\left(\mathbf{e V}^{\mathbf{- 1}}\right. \\
\left.\mathbf{c m}^{\mathbf{2}}\right)\end{array}$ & $\begin{array}{c}\boldsymbol{R} \boldsymbol{s} \\
(\mathbf{\Omega})\end{array}$ \\
\hline 30 & 3.207 & 0.4058 & 0.167 & 0.0152 & 0.558 & 1.92 & $2.53 \times 10^{9}$ & 298.89 \\
\hline 50 & 3.202 & 0.4358 & 0.168 & 0.0155 & 0.588 & 1.99 & $2.03 \times 10^{9}$ & 148.39 \\
\hline 100 & 3.228 & 0.4858 & 0.167 & 0.0160 & 0.637 & 2.12 & $1.77 \times 10^{9}$ & 79.80 \\
\hline 200 & 3.239 & 0.4958 & 0.167 & 0.0161 & 0.647 & 2.15 & $1.77 \times 10^{9}$ & 54.88 \\
\hline 300 & 3.180 & 0.5058 & 0.168 & 0.0161 & 0.657 & 2.15 & $1.86 \times 10^{9}$ & 48.34 \\
\hline 400 & 3.170 & 0.5258 & 0.168 & 0.0162 & 0.677 & 2.19 & $2.03 \times 10^{9}$ & 45.32 \\
\hline 500 & 3.160 & 0.5058 & 0.168 & 0.0161 & 0.658 & 2.14 & $2.13 \times 10^{9}$ & 45.04 \\
\hline 700 & 3.139 & 0.5258 & 0.168 & 0.0162 & 0.678 & 2.18 & $2.46 \times 10^{9}$ & 43.68 \\
\hline 1000 & 3.134 & 0.5458 & 0.168 & 0.0164 & 0.698 & 2.22 & $2.96 \times 10^{9}$ & 43.75 \\
\hline 2000 & 3.114 & 0.6258 & 0.168 & 0.0169 & 0.777 & 2.38 & $4.53 \times 10^{9}$ & 35.87 \\
\hline 3000 & 3.064 & 0.6558 & 0.169 & 0.0171 & 0.807 & 2.42 & $5.91 \times 10^{9}$ & 34.66 \\
\hline 4000 & 3.016 & 0.8558 & 0.169 & 0.0182 & 1.007 & 2.75 & $7.09 \times 10^{9}$ & 34.09 \\
\hline 5000 & 2.893 & 0.9258 & 0.170 & 0.0184 & 1.078 & 2.81 & $8.15 \times 10^{9}$ & 33.61 \\
\hline
\end{tabular}

As can be seen in Table 1, the calculated parameters have taken different values with varying frequencies. In addition to these results, the experimental impedance-voltage (Z-V) characteristics given in Figure 4d. It was clearly that the impedance values decreased with increasing frequency. The impedance values were not affected after at $1 \mathrm{~V}$.

To determine the electrical difference between Bis(TSC)-Rh and Bis(Rh), D2 device was fabricated and measured capacitance and conductance experimental values. In Figure 5a, the capacitance of D2 device decreased with increasing frequency. The conductance values increased with increasing frequency and applied voltage, as can be seen in Figure 5b. Some electrical characteristic parameters were calculated from $\mathrm{C}^{-2}-\mathrm{V}$ in Figure $5 \mathrm{c}$ as in D1 and given in Table 2. The $\mathrm{Z}-\mathrm{V}$ values measured in Figure 5d. The impedance values decreased with increasing frequency.

When D1 and D2 were compared with each other, D2 device capacitance and conductance performance was better than D1 device. As can be seen in Figure 4a and 5a, the capacitance values for D1 and D2 at $30 \mathrm{kHz}$ found to be $3.5 \mathrm{nF}$ and $4.3 \mathrm{nF}$, respectively. The reason for this difference can be attributed to more electrons trapping under the electric field of Rodanin molecules (Gulcin et al. 2018). 

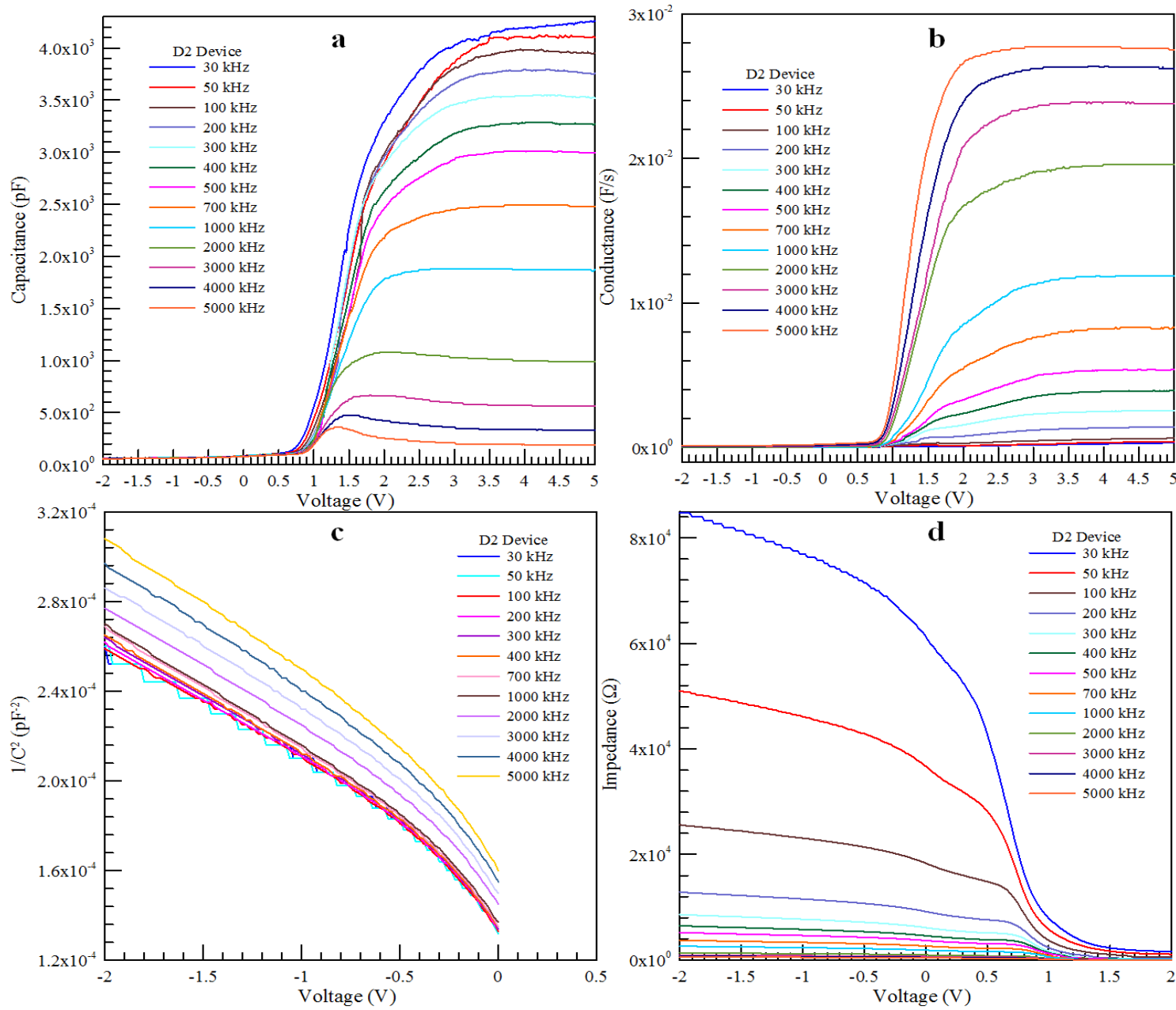

Figure 5. The electrical characteristics of $\mathrm{Bis}(\mathrm{Rh})-\mathrm{Ph} / \mathrm{p}-\mathrm{Si}$ Schottky diode at various frequencies a) $\mathrm{C}$ $\mathrm{V}$ measurement, b) G-V measurements, c) $1 / \mathrm{C}^{2}-\mathrm{V}$, d) $\mathrm{Z}-\mathrm{V}$ plot.

Table 2. The some electrical parameters of Bis(Rh)-Ph/p-Si Schottky diode MPS contact obtained from $\mathrm{C}-\mathrm{G}-\mathrm{V}$ and $\mathrm{C}^{-2}-\mathrm{V}$ at various frequencies

\begin{tabular}{ccccccccc}
\hline $\boldsymbol{f}(\mathbf{k H z})$ & $\begin{array}{c}\boldsymbol{N}_{\boldsymbol{a}}\left(\mathbf{c m}^{\mathbf{- 3}}\right) \\
\left(\mathbf{1 0}^{\mathbf{1 5}}\right)\end{array}$ & $\boldsymbol{V}_{\boldsymbol{d}}(\mathbf{V})$ & $\boldsymbol{E}_{\boldsymbol{F}}(\mathbf{e V})$ & $\begin{array}{c}\Delta \boldsymbol{\Phi}_{\boldsymbol{b}} \\
(\mathbf{e V})\end{array}$ & $\begin{array}{c}\boldsymbol{\Phi}_{\boldsymbol{b}} \\
(\mathbf{e V})\end{array}$ & $\begin{array}{c}\boldsymbol{E}_{\boldsymbol{m}}(\mathbf{V} / \mathbf{m}) \\
(\mathbf{1 0})\end{array}$ & $\begin{array}{c}\boldsymbol{N}_{\boldsymbol{s s}}\left(\mathbf{e V}^{\mathbf{- 1}}\right. \\
\left.\mathbf{c m}^{\mathbf{2}}\right)\end{array}$ & $\begin{array}{c}\boldsymbol{R} \boldsymbol{s} \\
(\mathbf{\Omega})\end{array}$ \\
\hline 30 & 4.201 & 1.12 & 0.160 & 0.0212 & 1.265 & 3.74 & $1.69 \times 10^{9}$ & 278.74 \\
\hline 50 & 4.103 & 1.07 & 0.161 & 0.0209 & 1.216 & 3.61 & $1.52 \times 10^{9}$ & 141.85 \\
\hline 100 & 4.025 & 0.92 & 0.162 & 0.0200 & 1.067 & 3.31 & $1.52 \times 10^{9}$ & 69.83 \\
\hline 200 & 3.864 & 0.84 & 0.163 & 0.0194 & 0.989 & 3.12 & $2.03 \times 10^{9}$ & 47.02 \\
\hline 300 & 3.780 & 0.77 & 0.163 & 0.0192 & 0.910 & 3.06 & $2.36 \times 10^{9}$ & 42.17 \\
\hline 400 & 3.669 & 0.76 & 0.172 & 0.0172 & 0.921 & 2.45 & $2.79 \times 10^{9}$ & 45.31 \\
\hline 500 & 3.658 & 0.77 & 0.164 & 0.0186 & 0.921 & 2.88 & $3.14 \times 10^{9}$ & 39.31 \\
\hline 700 & 3.617 & 0.82 & 0.164 & 0.0189 & 0.971 & 2.96 & $3.83 \times 10^{9}$ & 38.28 \\
\hline 1000 & 3.590 & 0.82 & 0.165 & 0.0189 & 0.972 & 2.95 & $4.79 \times 10^{9}$ & 37.28 \\
\hline 2000 & 3.579 & 1.07 & 0.164 & 0.0203 & 1.219 & 3.42 & $6.57 \times 10^{9}$ & 35.25 \\
\hline 3000 & 3.576 & 1.17 & 0.165 & 0.0206 & 1.320 & 3.53 & $8.27 \times 10^{9}$ & 34.00 \\
\hline 4000 & 3.473 & 1.27 & 0.165 & 0.0209 & 1.420 & 3.63 & $9.94 \times 10^{9}$ & 33.14 \\
\hline 5000 & 3.376 & 1.32 & 0.160 & 0.0210 & 1.471 & 3.65 & $1.16 \times 10^{9}$ & 32.81 \\
\hline
\end{tabular}


The series resistance of D1 and D2 devices ranges from 32 to $298 \Omega$. Especially, barrier height values of these devices are different. The barrier height of D2 device is greater than D1. So, the differences in barrier heights at various frequencies affect the capacitance and conductance values.

Structurally, Bis(TSC)- $P h$ and $B i s(R h)-P h$ could be considered a combination of TSC or Rh with 1,1'-(1,4-phenylene)bis(ethan-1-one) skeletons, having multiple hydrogen donoracceptor groups and heteroatoms. The sulfurcontaining molecules can easily convert into the thiol form and make stronger interactions with metal surfaces. However, the organic ligands containing a large number of conjugated benzene groups have always yielded good results for photo physical studies and they were always more interesting for researchers (Figure 6).
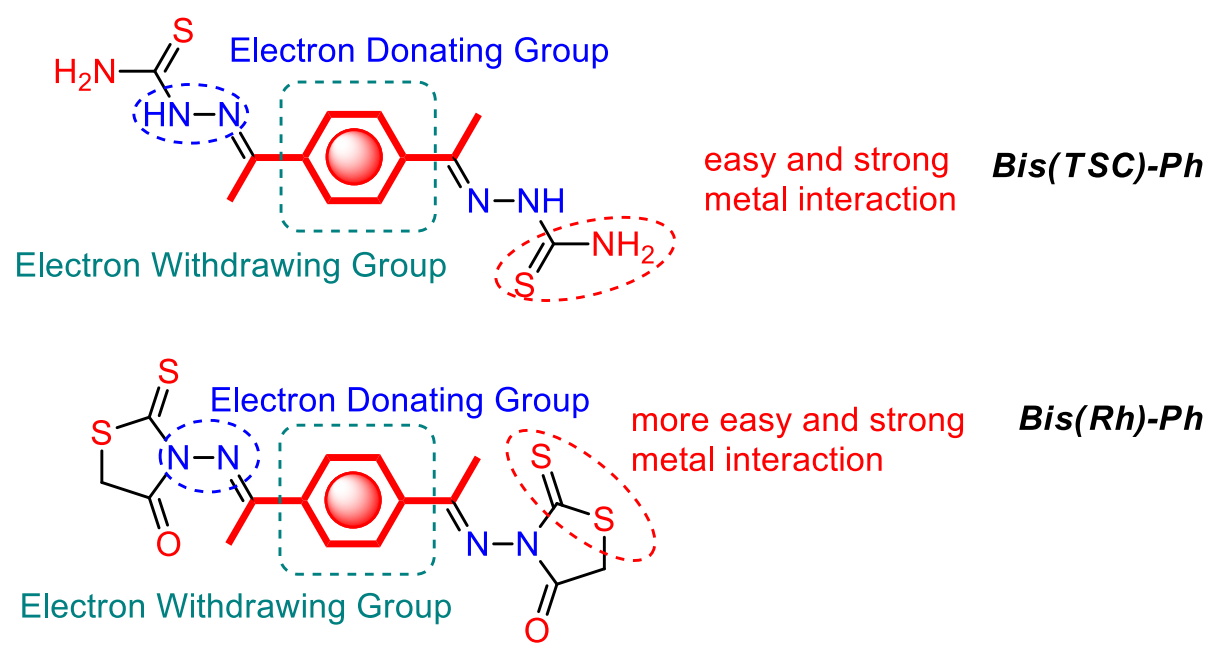

Figure 6. Structures of $B i s(T S C)-P h$ and $B i s(R h)-P h$

\section{CONCLUSION}

In this study, organic interface layers such as $\mathrm{Bis}(\mathrm{TSC})-\mathrm{Ph}$ and $\mathrm{Bis}(\mathrm{Rh})-\mathrm{Ph}$ were synthesized and successfully coated p-type silicon surface. The $\mathrm{Al} /(\mathrm{Bis}(\mathrm{TSC})-\mathrm{Ph} / \mathrm{p}-\mathrm{Si} / \mathrm{Al}$ and $\mathrm{Al} / \mathrm{Bis}(\mathrm{Rh})-\mathrm{Ph} / \mathrm{p}-\mathrm{Si} / \mathrm{Al}$ structures were fabricated by using spin coating and thermal evaporation technique. The basic electrical characteristics of these devices have been measured $\mathrm{C}-\mathrm{V}, \mathrm{G}-\mathrm{V}$ and $\mathrm{Z}-\mathrm{V}$ data taken in wide range of frequency from $30 \mathrm{kHz}$ to $5 \mathrm{MHz}$, at room temperature. The experimental results shown that both capacitance, conductance and impedance values are quite sensitive to the frequency. The Rs and $\mathrm{N}_{\mathrm{ss}}$ are also an significant parameters which reason a change in the conductance and capacitance. Especially, main electrical parameters of devices; such as the concentration of doping acceptor atoms $\left(\mathrm{N}_{\mathrm{a}}\right)$, barrier height $(\Phi)$ and Fermi energy level $\left(E_{F}\right)$ have been calculated from reverse bias $1 / \mathrm{C}^{2}-\mathrm{V}$ plots for each frequency. According to these experimental results, the electrical performance of $\mathrm{Al} /(\mathrm{Bis}(\mathrm{Rh})-\mathrm{Ph} / \mathrm{p}-\mathrm{Si}$ device is better than $\mathrm{Al} /(\mathrm{Bis}(\mathrm{TSC})-\mathrm{Ph} / \mathrm{p}-\mathrm{Si}$ device.

\section{REFERENCES}

Aksoy S, Caglar Y, 2012. Effect of Ambient Temperature on Electrical Properties of Nanostructure N-ZnO / p-Si Heterojunction Diode. Superlattices and Microstructures, 51(5), 613-25.

Bilkan C, Zeyrek S, San SE, Altindal S, 2015. A Compare of Electrical Characteristics in $\mathrm{Al} / \mathrm{p}-\mathrm{Si}$ (MS) and Al/C20H12/p-Si (MPS) Type Diodes Using Current-Voltage (I-V) and CapacitanceVoltage (C-V) Measurements, Materials Science in Semiconductor Processing, 32, 13744. 
Cifci OS, Kocyigit A, Sun P, 2018. Perovskite/p-Si Photodiode with Ultra-Thin Metal Cathode. Superlattices and Microstructures, 120, 492500 .

Güclü ÇŞ,Ozdemir AF, Karabulut A, Kökçe A, Altindal Ş, 2019. Investigation of temperature dependent negative capacitance in the forward bias $\mathrm{C}-\mathrm{V}$ characteristics of $(\mathrm{Au} / \mathrm{Ti}) / \mathrm{Al} 2 \mathrm{O} 3 / \mathrm{n}$ GaAs Schottky barrier diodes (SBDs). Materials Science in Semiconductor Processing, 89,26-31.

Gülcin ED, Yücedag I, Yashar AK, Altındal Ș, 2018. Temperature and Interfacial Layer Effects on the Electrical and Dielectric Properties of Al/(CdS-PVA)/p-Si (MPS) Structures. Journal of Electronic Materials, 47,11.

Kaçus H, Aydoğan Ş, Ekinci D, Kurudirek SV, Türüt A, 2015. Optical Absorption of the Anthracene and Temperature-Dependent Capacitancevoltage Characteristics of the $\mathrm{Au} / \mathrm{Anthracene} / \mathrm{n}$ $\mathrm{Si}$ Heterojunction in Metal-organicSemiconductor Configuration. Physica E: LowDimensional Systems and Nanostructures, 74, 505-09.

Karabulut A, 2019. Barrier height modification in $\mathrm{Au} / \mathrm{Ti} / \mathrm{n}-\mathrm{GaAs}$ devices with a $\mathrm{HfO} 2$ interfacial layer formed by atomic layer deposition. Bulletin of Materials Science, 42,5.

Karabulut A, Orak I, Canlı S, Yıldırım N, Turut A, 2018.Temperature-Dependent Electrical Characteristics of Alq3/p-Si Heterojunction. Physica B: Condensed Matter, 550, 68-74.

Kaya A, Marıl E, Altındal S, Uslu I, 2016. The Comparative Electrical Characteristics of $\mathrm{Au} / \mathrm{n}$ $\mathrm{Si}$ (MS) Diodes with and without a 2\% Graphene Cobalt-Doped Ca3Co4Ga0.001Ox Interfacial Layer at Room Temperature. Microelectronic Engineering, 149,166-71.
Liu J, Yi W, Wan Y, Ma L, Song H, 2008. 1-(1Arylethylidene)Thiosemicarbazide Derivatives: A New Class of Tyrosinase Inhibitors. Bioorganic and Medicinal Chemistry, 16, 10961102.

Majumdar M S, Chattopadhyay S, Banerji P, 2009. Electrical Characterization of $\mathrm{P}-\mathrm{ZnO} / \mathrm{p}-\mathrm{Si}$ Heterojunction. Applied Surface Science, 255, 6141-44.

Orak I, Urel M, Bakan G, Dâna A, 2015.Memristive Behavior in a Junctionless Flash Memory Cell. Applied Physics Letters, 233506,2-7.

Oruc FB, Aygun LE, Donmez I, Biyikli N, Okyay AK, 2015. Low Temperature Atomic Layer Deposited ZnO Photo Thin Film Transistors. Journal of Vacuum Science \& Technology A, 33, $01 \mathrm{~A} 105$.

Padma R, Sreenu K, Reddy VR, 2017. Electrical and Frequency Dependence Characteristics of Ti/Polyethylene Oxide (PEO)/p-Type InP Organic-Inorganic Schottky Junction. Journal of Alloys and Compounds, 695, 2587-96

Tanrıkulu EE, Demirezen S, Altındal S, Uslu I, 2018. On the Anomalous Peak and Negative Capacitance in the Capacitance-voltage $(\mathrm{C}-\mathrm{V})$ Plots of $\mathrm{Al} /(\% 7 \quad \mathrm{Zn}-\mathrm{PVA}) / \mathrm{p}-\mathrm{Si} \quad$ (MPS) Structure." Journal of Materials Science: Materials in Electronics, 29(4),2890-98. 